\title{
SCOTTISH EPISCOPAL CHURCH
}

\author{
IVOR GUILD
}

\section{Writer to the Signet}

A nuts-and-bolts Synod was how the Primus described the agenda in his opening remarks; and so it proved. A large amount of domestic housekeeping was dealt with.

\section{Eventide Homes}

The proposed closure of an eventide home generated much discussion and great warmth. A sum of $£ 500,000$ had been raised or promised to meet the cost of repairs and modernisation, but this was not enough to meet all the expenditure. In the end no decision was taken, and the matter was carried forward for further exploration of the possibilities. In the view of many the precipitate closure would be an act of folly and a lack of nerve.

\section{Child Protection}

Much work had been done in anticipation of the new Protection of Children (Scotland) Act, which comes into force in September 2004. It imposes onerous obligations on the Church, as on all organisations which look after children.

\section{Housing}

Housing at affordable rents is a national issue. The work of the Scottish Churches Action Group was commended, with a call for further funds to be made available. Allied to this plea was the need for housing for clergy on retiral. With the price of housing in Scotland increasing so dramatically, ways were discussed for help from other methods of financing.

\section{Training for the Ministry}

Last year it had been decided that Ministry Training should be delegated to dioceses, and a paper issued entitled 'New Century, New Directions'. A report was given on the carrying out of the vision of the paper, with, inevitably, a discussion on the costs of implementing the necessary changes. A central library had been retained, though there were uncertainties as to where it was to be housed. The Methodist Church had been part of the experiment and had been happy to participate. In connection with training it was felt that there ought to be an interfaith component. There were now more Muslims in Scotland than Episcopalian worshippers. Interfaith dialogue was essential; possibly those of other faiths should be invited to take part in Episcopalian services of worship.

\section{Canons}

As always, a number of canonical changes were considered, some for the first time. The Canon on Retiral of Clergy was clarified by making it clear 
that a stipendiary office in the Scottish Episcopal Church was not subject to compulsory retirement on account of age if the office had been held on 15 July 1991.

The Canon dealing with the Scottish Calendar (the list of Festivals to be celebrated and Holy Days to be observed) was proposed to be altered, so that changes could be made from time to time by motion approved by the Faith and Order Board without reference to the Synod. The alteration was passed without opposition.

Several Canons came up for second reading. The amendment dealing with the incapacity of bishops, which had been sent down to dioceses for their comments, was considered and passed without opposition. It dealt with the care of dioceses during such incapacity, and the housing and stipends of such bishops during incapacity.

A Canon dealing with incapacitated clergy was similarly passed. It provided for the suspension of a cleric without loss of emoluments until his case had been considered by the Medical Review Panel. It also dealt with the provision of services and the pastoral care of the congregation where such person was an incumbent. The bishop becomes responsible for making the appropriate temporary arrangements.

\section{Eucharistic Hospitality}

A first reading was given to Canon 25 'Of Admitting to Holy Communion'. This recognises the sacrament of Baptism as the full rite of initiation into the Church and allows the admission of any baptised person to Holy Communion at the discretion of the cleric in charge of the congregation. It further recognises as eligible to receive Communion any baptised person who is a communicant of any Trinitarian Church. It was pointed out that the new Canon did no more than set out what was, in fact, current practice.

A first reading was also given to a new Canon 28. The new Canon, headed 'Of Christian Education and Nurture', replaces one on 'Cathechising', updating the wording and emphasising the need to instruct children and young persons in the Faith. The Primus explained that it was not just a question of imparting knowledge, but of spiritual formation. Responsibility for this issue was placed on clergy, vestries and bishops.

\section{Membership}

One of the most heated debates of the Synod was on the subject of Church Membership. A Canon was proposed for the first time following the Report of a Working Party. It would make it the duty of every cleric in charge of a congregation to keep and revise a Pastoral Roll of the names and addresses of the members and adherents of the congregation. An Electoral Roll Secretary would have charge of the Roll and would receive applications for enrolment on it. It would be revised annually. A formal application 
form would require to be completed, and this would be interpreted as acceptance by the applicant of the legal responsibilities of membership. Only those on the Roll would be entitled to speak and vote at meetings or to stand for office.

There are three grounds for defining membership more accurately. The first is the legal one; difficulties can arise when a decision is needed in a congregation, and could also arise if there is civil liability for some act or omission by the congregation (which is an unincorporated association). At present the priest is charged with keeping a Communicants Roll, but worshippers are not required to give their consent to inclusion in it. Nor is it certain when an intermittent worshipper can claim to be included. The second is ecumenical. Often a person attends a church for social reasons or because it is their nearest ecclesiastical building. Their membership can be temporary or indecisive. Full participatory rights within the congregation have not been properly established. A third aspect is that some people worship in several different churches, possibly because they have houses or businesses in different places; this can leave it uncertain if they claim full membership of a particular congregation.

Some of the speakers felt that the change was necessary; others that form filling would deter people from joining a congregation - that the Canon was too heavy-handed and a barrier to new-comers. Despite the Canon being passed by the House of Bishops, it fell in the House of Clergy. Indications were that, had it gone to the House of Laity, it would have fallen there too.

\section{Initiation Rites}

In 1998 new initiation rites were approved by the College of Bishops for experimental use for a period of seven years. The Synod was asked to discuss these rites, which would then be sent to dioceses for further discussion. They would again be considered at the Synod in 2005, either to be added to the Schedule to Canon 22 (which would require only one reading), or to be treated as an alteration to that Canon (which would require two readings).

A questionnaire had already been issued to congregations; 74 per cent of those responding had made use of the new rites, responses had been generally favourable, use of them had been made at adult and private baptism, and 48 per cent of those responding had used them for Confirmation.

It was questioned whether only families with commitment to the Church would be happy with the new Rite of Baptism--indeed baptism seemed a better word to use for this initiation. The desirability of the new service of the Liturgy of the Laying on of Hands in affirmation of baptism in place of the existing Confirmation service was discussed, in particular whether the anointing and laying on of hands by a priest had the same sacramental significance as those acts performed by a bishop. 


\section{Scottish Church Initiative for Union (SCIFU)}

With the decision by the Church of Scotland not to continue in these discussions the enthusiasm for SCIFU talks had been reduced. None-theless the search for visible unity continues and modified plans for union with the Methodist Church and the United Reform Church were considered. Six recommendations were put forward, including re-affirmation of the commitment to the goal of full visible unity and approval of the SCIFU proposal in general terms as an appropriate model for pursuing this aim. It was suggested that the piloting of the model locally and more widely should be promoted where relations between any of the participating Churches were sufficiently developed. The Synod re-affirmed its commitment to the goal of full visible unity and welcomed the theological principles of the SCIFU Report; a motion, however, to approve the SCIFU proposal in general terms as an appropriate model was defeated; as was a motion to promote and facilitate the model locally and more widely. A more general motion to encourage the Inter-Church Relations Committee to continue fostering and deepening relationships with all other denominations in Scotland was passed by a majority.

\section{General Topics}

The usual number of separate topics were raised and discussed. The Global Arms Trade was deplored; the uncontrolled production and illegal transfer of arms was thought to fuel poverty and suffering throughout the world. The International Year of the Family was recognised and the Synod re-affirmed its commitment to support and enhance the effectiveness of local, national, and international awareness of family issues. Support was expressed for the Rural Focus Group and the need affirmed for exploration of new initiatives in Rural Life and Ministry. None of these required any follow-up action: none involved expense.

Of the matters discussed, some related merely to the machinery of administration, but others will inevitably recur. The proper training of priests is a basic requirement constantly to be updated; the definition of membership cannot be indefinitely postponed. While Christian Union has always been a Christian obligation, it has so far proved beyond the bounds of attainment; but it becomes more urgent as the strength of other faiths becomes greater in Britain. There is, moreover, a duty to seek greater understanding of the sincere beliefs and theology of other religions and to learn from them. It is doubtful if this nuts-and-bolts Synod gave much thought to such deeper issues. 